Jurnal Teknologi, 34(E) Jun 2001: 25-38

(C) Universiti Teknologi Malaysia

\title{
ASSESSMENT OF POTENTIAL OIL AND GAS EXPLORATION INVESTMENTS: MANAGEMENT PERSPECTIVE
}

\author{
RAZIF ABD. RAZAK*
}

\begin{abstract}
Assessment of potential oil and gas exploration investments is a crucial initial step for petroleum companies to ensure the success of the investments. The study explores the decision-making processes of the upstream investments in U.S. petroleum companies. Two hundred and twenty-one high-level decision-makers representing 221 U.S. petroleum companies completed mail questionnaires concerning decision-making processes in assessing potential oil and gas exploration investment employed by their firms. The result of the study established and empirically described the management view of the current practices of assessing oil and gas exploration investments. The study also identifies the relationships between the decision-making processes and the performance of the company.
\end{abstract}

\subsection{INTRODUCTION}

For a petroleum company, assessing potential oil and gas exploration investments is a complex process and it is one of the important steps that influences the success of the investments [Barry, 1993]. The success of the oil and gas exploration investments will ultimately influence performance of the petroleum company. Investment decisions on oil and gas exploration demand thorough analysis of the economic and non-economic feasibility of embarking on such projects (Quick and Buck, 1983; Larche, 1992). According to Hailey et al., (1992) “...the importance of decision-making in oil and gas exploration places a greater demand on decision-makers and the tools employed in their decision-making. Health and the ultimate survival among the firms within the industry require that the decision-making processes utilized match the global competitive pressure being placed upon the industry."

The OPEC crisis in 1973 and 1979 resulted in a marked increase in the average oil price to almost $\$ 36$ per barrel (1993 U.S. Dollars) between 1973 and 1985 (Anonymous, 1996). In those periods, oil companies reaped substantial profit from the increase in the oil price (Nulty, 1991; Anonymous1, 1986). The assumption that oil prices would stay high led oil companies to invest in expensive exploration and nonexploration ventures in high-risk areas as well as to operate with uncontrolled overhead (Wiegner, 1986). In the early 1980s many expected that oil prices would reach $\$ 50$ per barrel by 1990 (Huntington, 1994; Baum, 1989). During this period, many

* Petroleum Engineering Department, Faculty of Chemical and Natural Resources Engineering, Universiti Teknologi Malaysia, 81310 Skudai, Johor Darul Takzim. Malaysia. 
bad business decisions in exploration were not evident in the companies' performance due to profits gained from the high oil price (Quick, 1982). However, oil prices crashed in 1986 to below $\$ 10$ per barrel due to excessive supply relative to demand (Anonymous2, 1986, Anonymous3, 1986). This left the oil companies with many losses from their costly $\mathrm{E} \& \mathrm{D}$ and reserve acquisition investments (Wiegner, 1986). In response to low oil prices, increased competition, tougher environmental laws and shrinking profits, the petroleum industry has changed the way it conducts business. Most of petroleum companies have reorganized and are placing greater emphasis on utilization of technology to enhance productivity and increase efficiency (Treat, 1996). Petroleum companies have also become more environmentally conscious in response to public and government concern regarding the impact of their activities on the environment and also due to the highly publicized events such as the costly Valdez oil spill accident in Alaska in 1989 (William, 1991).

In terms of new exploration opportunities, there is a trend of petroleum companies including PETRONAS to look more toward foreign opportunities in less developed countries for E\&D and reserve acquisition investments (Anonymous, 2000). This is due to the fact that most areas especially in the developed countries have been extensively explored and few new prospects remain for big discoveries (Koen, 1996). Vast oil and gas exploration opportunities exist in the former Soviet Union, Eastern Europe, Latin America and Asia (Anonymous, 1996; Anonymous, 1995). These countries have great geological potential but neither possesses sufficient capital nor adequate technology and management expertise to effectively exploit their natural resources. Naturally, this situation provides opportunities for petroleum companies for their exploration and reserve acquisition investments. However, the attractiveness of these opportunities depends heavily on the fiscal terms and other requirements imposed by the host government. Petroleum companies are also confronted by political risks, which they must be willing to take when investing in these countries. Therefore, technical assessment of potential size of discovery needs to be combined with non-technical evaluation such as political risk, alignment with company's goals and objectives and attractiveness of fiscal terms in petroleum agreement with the host government. A literature review in this area reveals that there is limited information available on how petroleum companies actually identify, evaluate and select their petroleum E\&D investments (Abd. Razak, 1995). This is an exploratory study to empirically describe the decision-making processes from management perspective by gathering data from decision-makers in petroleum industry. The objectives are to investigate the decision processes of evaluation and selection of oil and gas exploration investments from management perspective of petroleum companies as well as to identify the relationships between decision processes and the performance of the company. The study was based on empirical data collected from U.S. petroleum companies. 


\subsection{RESEARCH METHODOLOGY}

The first part of the study describes how the actual decision-making processes of identification, evaluation and selection of petroleum E\&D work in a company. Figure 1 depicts the schematic diagram of the conceptual decision-making processes, which is applicable to the petroleum industry as well as to other industries. The conceptual model of decision-making processes was developed based on the literature review. The decision making components included in the model are the objectives of the investments, the information sources used to identify the investments, the influencing variables, the methodologies used, and the sources of information used for the evaluation and selection (E\&S). The initial questions that asked for descriptions of the decision-making processes of petroleum $\mathrm{E} \& \mathrm{D}$ investments were as follows:

(i) What are the investment objectives?

(ii) What information sources are used to identify the project alternatives?

(iii) What methodologies are used for $\mathrm{E} \& \mathrm{~S}$ ?

(iv) What information sources are used for E\&S?

(v) What influencing variables are taken into consideration in E\&S?

(vi) What is the performance of the company?

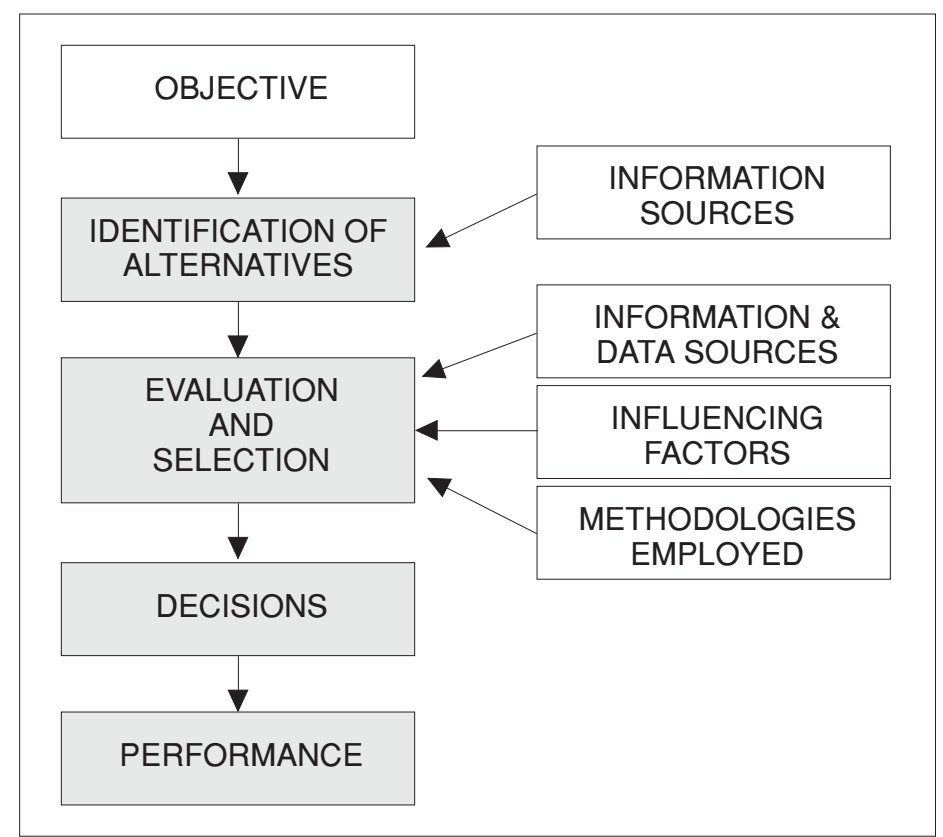

Figure 1 Decision process schematic model 
To answer these questions, an extensive literature search was conducted, relevant information was gathered and a survey instrument was developed incorporating the decision-making components above. The items for each decision-making component were identified from the synthesis of the literature. The questionnaire was then developed to collect empirical data regarding decision-making processes in oil and gas exploration investment. The questionnaire was designed to investigate decisionmaking components in identification, evaluation and selection of petroleum E\&D by measuring the relative importance of each item in each component. The components include objectives of the investments, sources of information for identification, methodologies used, influencing variables, sources of information for evaluation and selection, and performance of the company as perceived by a decisionmaker.

The questionnaire then was evaluated and validated by a panel of experts from petroleum industry who made suggestions to modify and finalized the questions and the items used. Their comments and suggestions were incorporated in the final version of the questionnaire. The members of the expert panel are listed in Appendix A. Each decision-making component comprises several items. Summary of top three groups of items under each decision-making component are presented in results Section (3), Table 3.

The second part of the study consisted of the collection of empirical data from decision-makers in the petroleum companies on the relative importance of each objective, the extent of usage of each information source for identification, the extent of usage of each methodology, the extent of usage of each information source for $E \& S$ and the level of consideration of each influencing variable in E\&S. The data was collected using a mail survey that was sent to petroleum companies.

\subsection{SURVEY RESPONDENTS}

The target population of the research was all US petroleum companies involved in exploration and development activities. The sampling frame used for the survey was the 1997 U.S.A Oil Industry Directory, 36th edition (published annually by Pennwell Publishing Company). Eight hundred and sixty four petroleum companies were identified in the 1997 directory that is involved in such activities. According to the publisher, the directory contains most of the petroleum companies in the US. Therefore, it is a reasonable representation of the US petroleum companies. To get management perspective, the survey questionnaire was sent to the vice president of exploration and development of each company. When no person was listed for that position, the survey was directed to the owner, president or CEO of the company. The questionnaires were sent to a total of 864 companies, however 40 were returned due to invalid addresses; 35 companies responded that their activities were no longer relevant to the questionnaire due to mergers and acquisitions or going out 
of business. Two hundred and twenty one companies completed the questionnaire. Eighteen and a half percent of the respondents in the sample were publicly traded companies. The distribution of companies that participated in the study categorized by size of average annual exploration and capital expenditure (CAPEX) in the last three years. The average annual CAPEX of most of the responded companies is $\$ 1$ to 10 million. That segment represents $45.4 \%$ of the sample; $24.3 \%$ spend less than $\$ 1$ million, and 7.6\% spend more than $\$ 200$ million. The rest of the companies are between 11 and 200 million (14.6\% in the 11 and 50 million range, $8.1 \%$ in the 51 200 million range). Figure 2 shows the distribution titles of survey respondents.

\section{TITLES OF RESPONDENTS}

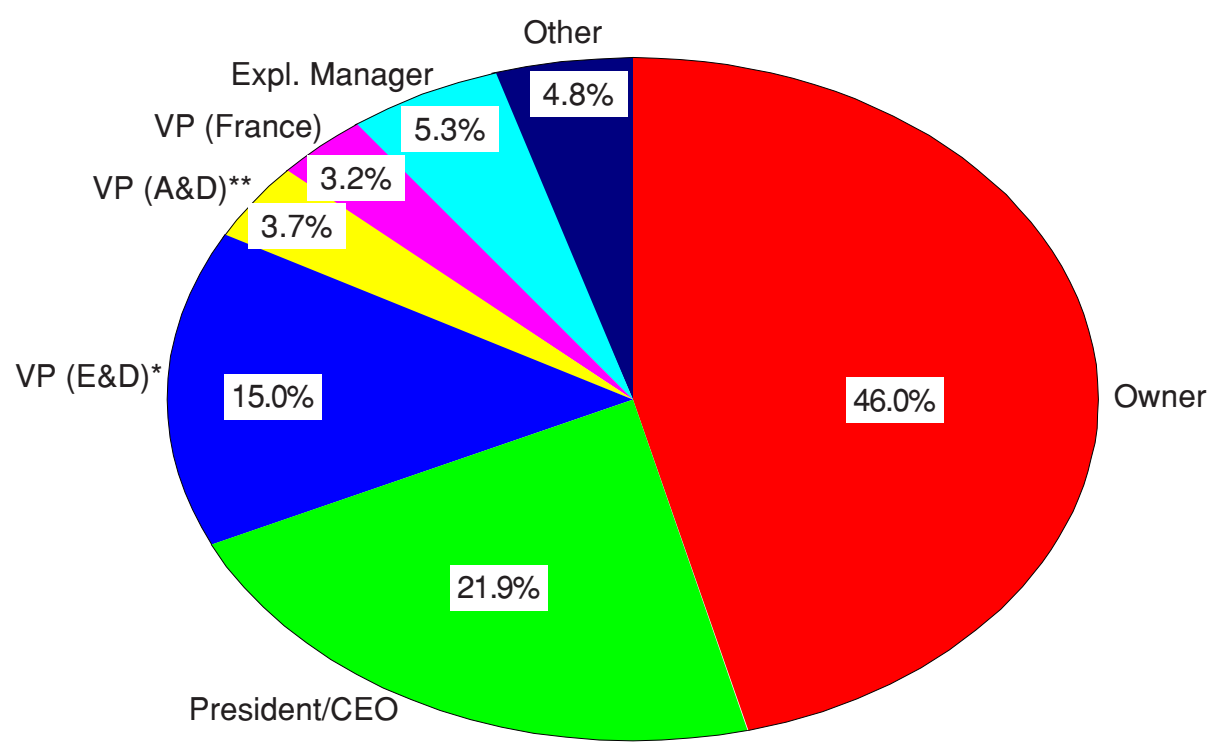

Figure 2 Titles of the survey respondents.

*Exploration \& Development

${ }^{* *}$ Acquisition \& Divestment

\subsection{RESULTS}

Table 1 shows an example of the mean scores of level of consideration of each influencing variable in oil and gas exploration investments, which is one of the decision-making components. The mean scores of perceived performance is presented as well. The scores of items of other decision-making components are not presented due to lack of space, however table 3 summarized the results. 
Table 1 Level of consideration of each influencing variables in project E\&S

\begin{tabular}{|l|c|}
\hline Influencing Variables & Mean Scores \\
\hline Geological Potential & 4.61 \\
Potential Exploration and Development Cost & 4.24 \\
Alignment with Company's Goals, Objectives, and Strategies & 4.04 \\
Geographical Locations & 3.77 \\
Technological Requirements & 3.65 \\
Synergy with Existing Operations & 3.57 \\
Existing Infrastructure & 3.51 \\
Oil and Gas Price Forecasts & 3.50 \\
Company's Short Term Cash Flow & 3.39 \\
Environmental Considerations & 3.34 \\
Fiscal Regimes & 2.65 \\
Competitors & 2.57 \\
Political Risk & 1.73 \\
1 = not considered, and 5 = extensively considered & \\
\hline
\end{tabular}

Table 2 Extent of agreement with each performance measure

\begin{tabular}{|l|c|}
\hline Perceived Performance in the last 3 years & Mean Scores \\
\hline Average return on assets improved & 4.25 \\
Revenues of the company improved & 4.05 \\
Profits of the company improved & 3.88 \\
Average finding and development cost decreased & 3.76 \\
Reserve holding of the company increased & 3.20 \\
1 = strongly disagree, and 5 = strongly agree & \\
\hline
\end{tabular}

The first part of the analysis was "Repeated Measures ANOVA," which was performed to test significant differences among means, and when found significant, a follow-up Tukey's honestly significant difference (HSD) was used to determine which group means were different. The summary of results is presented in Table 3 below.

Table 3 Summary of results form Anova and Tukey's HSD

\begin{tabular}{|l|l|}
\hline $\begin{array}{l}\text { Decision Making } \\
\text { Component }\end{array}$ & $\begin{array}{l}\text { Top Three Items Within Each Decision-Making } \\
\text { Component }\end{array}$ \\
\hline Investment Objectives & $\begin{array}{l}\text { 1. Replace and/or Increase Reserve } \\
\text { Maximize Profit }\end{array}$ \\
& $\begin{array}{l}\text { 2. Reduce Finding and Development Cost } \\
\text { Increase Production Rate Capability } \\
\text { 3. Reserve Area Diversification }\end{array}$ \\
\hline
\end{tabular}




\begin{tabular}{|c|c|}
\hline $\begin{array}{l}\text { Decision Making } \\
\text { Component }\end{array}$ & $\begin{array}{l}\text { Top Three Items Within Each Decision-Making } \\
\text { Component }\end{array}$ \\
\hline $\begin{array}{l}\text { Information Sources } \\
\text { Used for Project } \\
\text { Identification }\end{array}$ & $\begin{array}{l}\text { 1. In-house Research } \\
\text { 2. Company Solicitations } \\
\text { 3. Consultants }\end{array}$ \\
\hline $\begin{array}{l}\text { Capital Budgeting } \\
\text { Methodologies }\end{array}$ & $\begin{array}{l}\text { 1. Net present value (NPV) } \\
\text { Payback Period } \\
\text { Internal Rate of Return } \\
\text { 2. NPV/Investment Ratio } \\
\text { 3. Accounting Rate of Return }\end{array}$ \\
\hline $\begin{array}{l}\text { Risk Assessment } \\
\text { Methodologies }\end{array}$ & $\begin{array}{l}\text { 1. Subjectively Determined } \\
\text { 2. Sensitivity Analysis } \\
\text { Variance of NPV } \\
\text { Scenario Analysis } \\
\text { 3. Decision Tree }\end{array}$ \\
\hline $\begin{array}{l}\text { Risk Adjustment } \\
\text { Methodologies }\end{array}$ & $\begin{array}{l}\text { 1. Subjectively Made Adjustment. } \\
\text { 2. Risk Adjustment Discount Rate } \\
\text { 3. Certainty Equivalent Approach }\end{array}$ \\
\hline $\begin{array}{l}\text { Management Science } \\
\text { Related Methodologies }\end{array}$ & $\begin{array}{l}\text { 1. Statistical Analysis } \\
\text { 2. Decision Theory } \\
\text { Goal Programming } \\
\text { PERT/Critical Path } \\
\text { Linear \&/or Interger Programming } \\
\text { Analytic Hierarchy Process } \\
\text { 3. Non-linear Programming } \\
\text { Game Theory }\end{array}$ \\
\hline $\begin{array}{l}\text { Political Risk Assessment } \\
\text { Methodologies }\end{array}$ & $\begin{array}{l}\text { 1. Subjective Judgement } \\
\text { 2. Personal Visit } \\
\text { 3. Expert Panel } \\
\text { Decision Tree } \\
\text { Rating Index }\end{array}$ \\
\hline Influencing Variables & $\begin{array}{l}\text { 1. Geological Potential } \\
\text { 2. Potential Exploration \& Development Cost } \\
\text { Alignment with Company's Goals, Objectives and Strategies } \\
\text { 3. Geographical Locations } \\
\text { Technological Requirements } \\
\text { Synergy with Existing Operations } \\
\text { Existing Infrastructure } \\
\text { Oil and Gas Price Forecasts } \\
\text { Company's Short-term Cash Flow } \\
\text { Environmental Considerations }\end{array}$ \\
\hline $\begin{array}{l}\text { Information Sources } \\
\text { Used for Evaluation } \\
\text { and Selection }\end{array}$ & $\begin{array}{l}\text { 1. In-house Expertise } \\
\text { Past Experiences } \\
\text { 2. Industry Sources } \\
\text { Proprietary Sources } \\
\text { 3. Commercial Sources }\end{array}$ \\
\hline
\end{tabular}


Table 3 summarizes the results of the analyses. It lists the top three items within each decision making component that have statistically significant differences from one another, when multiple item are listed in one group, it indicates that there is no statistically significant difference between the items within the group. For example, for the investment objectives "replace and/or increase reserve," and "maximize profit" are the most important group of objectives and they constitute one group because there is no statistically significant difference between their levels of importance. The second group of objectives consists of "reducing finding and development cost" and "increasing production rate capability." The first group of objectives is significantly $(p<0.05)$ more important than the second group. Finally, objectives in the second group are significantly $(\mathrm{p}<0.05)$ more important than the third group.

Principal component factor analysis was then utilized to summarize information at item level within each decision-making component and factors derived from the analysis were then used for multiple regression analysis. The criteria that were used to decide how many factors to retain were eigenvalues greater than one and interpretability of factor (Hair, 1995). A scree plot was also utilized to identify the optimum number of factors to be extracted. Initially, the unrotated factor analysis was run to give the best linear combination of variables on the first factor. Then, other rotations such as varimax, quartimax and equimax were performed to get the best interpretable factors that conform to eigenvalues greater than one. The main objective of rotation is to get simple interpretable factors (Sharma, 1996). From the analysis, it was found that the varimax rotation gave the best result in terms of interpretability. The main goal of varimax rotation is to have a factor structure whereby each variable loads highly onto one factor thereby producing a factor structure with distinct construct (Sharma, 1996). The eigenvalue represents the proportion of variance explained by each factor. In interpreting factors, loadings that are equal to or greater than 0.5 are considered significant. In naming the factors, a substantive interpretation was made based on significant variables and their relative strength in factor loading. It is noted that the naming process is a combination of analytical results and subjective judgment (Hair, 1995). Table 4 shows an example of the results of factor analysis performed on influencing variables in oil and gas exploration investments. Three factors with eigenvalues of $3.41,1.73$ and 1.32 , respectively, were extracted from the analysis. They cumulatively accounted for $50 \%$ of the total variance. Table 5 presents the summary of results of the factor analysis performed on all of the decision-making components.

Another objective of the study was to investigate if a relationship exists between the decision-making processes and performance. Specifically, the relationship between the level of importance of investment objectives, the extent of usage of methodologies used for E\&S and the level of consideration of influencing variables, and the performance of the company. To accomplish this objective a stepwise multiple regression analysis was used to examine the relationship. Stepwise approach is able 
Table 4 Factor analysis on influencing variables

\begin{tabular}{|l|c|c|c|}
\hline & $\begin{array}{c}\text { Factor 1 } \\
\text { (Strategic } \\
\text { Variables) }\end{array}$ & $\begin{array}{c}\text { Factor 2 } \\
\text { (Governmental } \\
\text { Variables) }\end{array}$ & $\begin{array}{c}\text { Factor 3 } \\
\text { (Geological } \\
\text { and Financial } \\
\text { Variables) }\end{array}$ \\
\hline Geological potential & .012 & .297 & $\mathbf{. 6 8 6}$ \\
\hline Fiscal regimes & .040 & $\mathbf{. 7 4 7}$ & .144 \\
\hline Political risk & .128 & $\mathbf{. 7 3 5}$ & .087 \\
\hline Oil and gas price forecast & $\mathbf{. 6 8 5}$ & -.067 & -.121 \\
\hline Technological requirements & $\mathbf{. 5 1 7}$ & .382 & .124 \\
\hline Existing infrastructure & $\mathbf{. 6 4 7}$ & .296 & -.055 \\
\hline Synergy with existing operations & $\mathbf{. 7 6 7}$ & -.208 & -.015 \\
\hline Environmental considerations & $\mathbf{. 6 1 9}$ & .115 & .241 \\
\hline Geographical locations & $\mathbf{. 4 6 4}$ & -.405 & .344 \\
\hline Potential exploration \& development cost & .241 & .044 & $\mathbf{. 7 9 9}$ \\
\hline Company's short-term cash flow & -.040 & -.018 & $\mathbf{. 6 0 4}$ \\
\hline Competitors & .414 & .236 & .308 \\
\hline Alignments with company's goals, & & & .258 \\
\hline strategies, and objectives & $\mathbf{. 5 1 8}$ & .178 & \\
\hline
\end{tabular}

Table 5 Factors obtained from factor analysis for each decision-making component

\begin{tabular}{|c|}
\hline Investment Objectives \\
\hline Efficiency and Risk Reduction \\
\hline Revenue enhancement \\
\hline \\
\hline Information Sources Used for Identification \\
\hline Publicly Available Information Sources \\
\hline Specialized Information Sources \\
\hline Internal Information Sources \\
\hline \\
\hline Methodologies \\
\hline Analytical Methods \\
\hline Interest Based Financial Methods \\
\hline Subjective Political Risk Assessment Methods \\
\hline \\
\hline Influencing Variables \\
\hline Strategic Variables \\
\hline Governmental Variables \\
\hline Geological and Financial Variables \\
\hline \\
\hline Information Sources for Evaluation and Selection \\
\hline Publicly Available Information Sources \\
\hline Specialized Information Sources \\
\hline Internal Information Sources \\
\hline
\end{tabular}


to select the smallest numbers of independent variables that maximize the prediction of dependent variable (Hair et al., 1995). Factor scores from the factor analysis were utilized for the regression. The final equation obtained from the regression analysis is presented below:

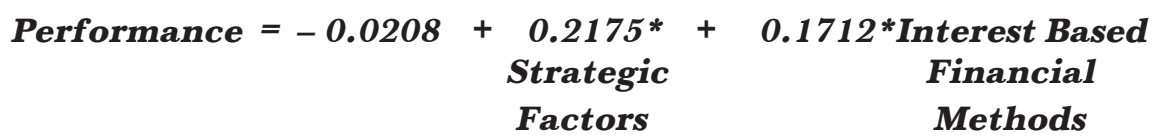

There is an overall significant relationship between "Strategic Factors (SF)," "Interest Based Financial Methods (IBFM)" and performance of the company $(F=8.514, p=0.00031)$. The equation explained approximately $10 \%$ of the unique variance with Strategic Factors (Beta $=0.214, p<0.01$ ) provided a relatively stronger contribution compared to Interest Based Financial Methods (Beta $=0.163, p<0.05$ ). The $\mathrm{R}$ square value of $10 \%$ is reasonable considering this is an exploratory study, and there are many internal and external factors not included in this study that directly influence petroleum companies' performance such as management efficiency and oil price. The result from the regression analysis reveals that a statistically significant relationship exists between Strategic Factors, Interest Based Financial Methods and the performance of companies.

\subsection{DISCUSSION}

The study found that replace and/or increase reserve and maximize profits are the two most important investment objectives. Replace and/or increase reserve objective is related more to the long-term survival of the company, meanwhile profit maximization is strongly related to short-term performance. By rating these two objectives as equally important, it essentially says long-term survival is equally important with short-term performance. An important motivation behind E\&D investment decisions from a petroleum company viewpoint is to maximize value of the investment by finding, developing and producing petroleum at the lowest cost (Larche, 1992; Johnston, 1996). Petroleum reserve is the major element influences performance and determines the survival of the company in the future (Hossain, 1979).

After the collapse of oil prices in 1986, prices have remained relatively low, pushing oil companies to increase their operational efficiency in order to improve profit margins (Knott, 1996; Wardt, 1996). The results in this study showed that increasing operational efficiency such as reducing finding and development cost, and increasing production capability are important. They were placed second after the replacing and/or increasing reserve and maximizing profit. In the last decade, oil companies have made significant improvement in their operations such as aggressive utilization of technologies, cost controls, and utilization of engineering management concepts such as TQM and reengineering (Treat, 1996). 
The most popular methodologies used in the petroleum industry are NPV, payback period and IRR. The results agree with the previous studies (Boyle and Schenck, 1985; Dougherty and Sarkar, 1993). In assessing financial and political risks, the most popular method is subjective assessment. This is in line with what was suggested by Kobrin [1983], that most of U.S. multinational companies use intuitive judgment to evaluate political risk. Quantitative methods such as sensitivity analysis, variance of NPV, and scenario analysis are among other popular methodologies that are used to assess risk. Non-financial quantitative methodologies such as decision theory, goal programming and simulation are not widely used. It is likely that these methodologies are less popular because of their complexity, they require more extensive data, and people in the petroleum industry have less exposure to these methodologies. It is certainly a challenge for academics to promote strengths and benefits of these methodologies in facilitating decision making for the industry. The most popular non-financial quantitative method is statistical analysis, and the result agrees with the study conducted by Hailey et al. (1992). A general pattern is that companies prefer simple and easy-to-use methodologies in evaluation and selection of projects. Similar pattern was observed in the U.S. electronic manufacturing industry (Daim, 1998).

Previous studies conducted by Broadman (1985) concluded that geological potential is necessary but not sufficient for exploration investment to take place. Other variables such as economics, institutional and political factors also play essential roles in the investment decision. The findings in this study verified that conclusion and expanded it by identifying the influencing variables and their relative measures according to a decision-maker's viewpoint. It was found that geological potential is indeed the most important factor considered in oil and gas exploration investments, other variables were identified as well. Geological potential is critical because the key activities of the companies are to find, develop and produce petroleum (Burke, 1992). The second most important variable considered is potential $\mathrm{E} \& \mathrm{D}$ cost. This variable directly influences the profitability of the projects. It supports one of the most important investment objectives established in this research, which is profit maximization. Alignments with company's goals, objectives and strategies are the next most considered influencing variables. It supports suggestions by Larce (1992), Quick and Buck (1983) and Quick (1982) that strategic planning for exploration management plays an important role in an exploration decision. The high ranking of this variable is probably also due to the fact that most of the respondents were from top management position such as owner, president and vice president of the company who are involved in setting and influencing the direction of the company's goal, objectives and strategies. To assess the influencing variables, the most important sources of information used are in-house research and past experiences, followed by industry and proprietary sources then commercial sources. In-house research is the most important information source used by companies either to identify or to evaluate and select projects. 
In relation to the second objective of the study, it was found that there is a statistically significant relationship among the extent of usage of Interest Based Financial Methods (IBFM), the level of consideration of Strategic Factors (SF), and the performance of companies. A closer look at the SF that was obtained using factor analysis reveals that extensive consideration of synergistic with the current operations, oil and gas price forecasts, existing infrastructure, environmental, technological requirements and alignments with company's goals, objectives and strategies did contribute to the variance of companies performance. Furthermore, to a lesser extent, IBFM that consists of net present value (NPV), internal rate of return (IRR), NPV/Investment Ratio, Variance of NPV, Sensitivity Analysis and Risk Adjusted Discount Rate also contribute to the variance of companies' performance.

\subsection{CONCLUSIONS}

The results describe the decision-making processes of petroleum exploration investments. The study established the decision-making process model supported by empirical relative measures of each item within each decision-making process component. There are significant positive relationships between decision-making processes and the performance of the company. Specifically, the extent of usage of Interest-Based Financial Methods (IBFM) and the level of consideration of Strategic Variables (SV) are correlated with performance of the companies. Based on the findings of the study, in assessing potential oil and gas exploration, petroleum companies are advised to put heavy emphasis on forecasting oil and gas prices, technology requirements, existing infrastructure, synergy with existing operations, environmental considerations, geographical locations, and the alignments with company's goals, strategies, and objectives in addition to evaluating geological potential. Furthermore, the companies are encouraged to utilize more of the interest-based financial methodologies such as NPV, IRR, NPV/investment ratio, variance of NPV, sensitivity analysis and risk adjustment discount rate. Additionally, it is advisable for petroleum companies to compare their decision-making processes with Table 3 as a benchmark for the decision-making process in the petroleum industry, which is empirically gathered from the industry.

\subsection{ACKNOWLEDGEMENT}

This project was supported by the Engineering and Technology Management Department, Portland State University, USA.

\section{REFERENCES}

Abd. Razak. M. R., Evaluation and Selection of Petroleum Exploration and Production Projects: Literature Survey. 1995. Engineering and Technology Management Department, Portland State University: Portland, OR. 
Anonymous1. 1986. Skidding, All in a Row, in Economist. 301. Nov 22: 66.

Anonymous2. 1986. Even Big Oil Must Shrink. Economist. 209. April 5: 85 - 86.

Anonymous3.1986. Big Oil Peers into the Abyss. Economist. 300. July 19: 51 - 52.

Anonymous. 1989. Oil Company Strategy: Lean Machines. 309. Economist, Sept. 23: 84 - 89.

Anonymous. 1994. Exxon to Appeal Valdez Spill Judgment. Oil and Gas Journal, 92(39): 36 - 38.

Anonymous. 1995. Oil, Gas and Coal Supply Outlook: International Energy Agency.

Anonymous. 1996. World Energy Outlook. Paris, France: Organization for Economic Co-operation \& Development (OECD).

Anonymous. 2000. Pillars of Success. Petromin. 26(4): 12 - 20.

Barry, R. 1993. The Management of International Oil Operations. Tulsa, Oklahoma: Pennwell Publishing Company.

Baum, V. 1989. Incentives for Oil Exploration. Petroleum Economist, Oct.: 307 - 309.

Boyle Jr., H. F. and G. K. Schenck. 1985. Investment Analysis: U.S. Oil and Gas Procedures Score High in University Survey. Journal of Petroleum Technology. 37(April): 680 - 690.

Broadman, H. G. 1985. Corporate Strategies of Foreign Investment in Oil Exploration Outside North America. The Journal of Energy and Development. 13(1): 27 - 44.

Burke, F. M. J. and R. D. Dole. 1992. Business Aspects of Petroleum Exploration in Non-Traditional Areas. Dallas: $\mathrm{BMC}$, Inc.

Daim, U. T. 1998. "Technology Evaluation and Acquisition Strategies and Their Implications in the U.S. Electronic Manufacturing Industry,” Ph.D. Dissertation. Portland State University.

Dougherty, E. L. and J. Sarkar. "Current Investment Practices and Procedures: Result of a Survey of U. S. Oil and Gas Producers and Petroleum Consultants," Presented at SPE Hydrocarbon Economics Symposium, Dallas, Texas, USA, 29 - 30 March 1993.

Hailey, W. A., E. J.J. Ryan, C. W. Barnes, and C. K. Woodruff. 1992. Strategic Resources Allocation Processes and the Use of Quantitative methods in Evaluation of Plays in Oil and Gas Exploration. Petroleum Accounting and Financial Management Journal. 11(1). 78 - 95.

Hair, J. F., R. E. Anderson, R. L. Tatham and W. C. Black. 1995. Multivariate Data Analysis. Fourth Edition. Upper Saddle River, New Jersey: Prentice Hall.

Hossain, K. 1979. Law and Policy in Petroleum Development: Changing Relations Between Transnationals and Governments. New York: Nichols Publishing Company.

Huntington, H. G. 1994. Oil Price Forecasting in the 1980s: What Went Wrong? The Energy Journal. 15(2): 1 - 22.

Johnston, D. 1996. International Petroleum Fiscal System and Production Sharing Contracts. Tulsa, Oklahoma: Pennwell Publishing Company.

Knott, D. BP Sharpening Focus on Improved Shareholder Value, Efficiency. in Oil and Gas Journal, July 8: $22-26$.

Kobrin, S. 1983. Managing Political Risks Assessment: Strategic Response to Environmental Change. Berkeley: University California Press.

Koen, A. D. 1996. U.S. Independent Operators Seek International Opportunities, Part 2. Oil and Gas Journal. Mac. 11: 33: 38

Larche, I. 1992. Oil Exploration: Basin Analysis and Economics. San Diego: Academic Press.

Newendorp, P. D. 1975. Decision Analysis for Petroleum Exploration. Tulsa, Oklahoma: The Petroleum Publishing Company.

Nulty, P. 1991. Oil's Prospects: A Better Decade, in Fortune. April 22: 139 - 144.

Quick, A. N. 1982. Exploration Strategy: An Integral Part of Strategic Planning. Oil \& Gas Journal, Sept. 27: $286-300$.

Quick, A. N. and N. A. Buck. 1983. Strategic Planning for Exploration Management. Boston: D. Reidel Publishing Company.

Sharma, S. 1996. Applied Multivariate Technique. New York: John Wiley \& Son, Inc.

Treat, J. E. 1996. Creating the High Performance International Petroleum Company: Dinosaurs Can Fly. Tulsa, Oklahoma: Pennwell Publishing Company.

Wardt, J. P. 1996. Operational Realities of the '90s. in World Oil. Feb.: 110 - 113.

Wiegner, K. 1986. Regrets. Forbes, March 10: 32 - 34.

William, B. 1991. U.S. Petroleum Strategies in the Decade of the Environment. Tulsa, OK: Pennwell. 


\section{APPENDIX A}

\section{Expert Panel Members}

1. Prof. Marlan Downey - Director, Chief Scientist, Sarkeys Energy Center, University of Oklahoma (A former President of ARCO)

2. Ron W. Pritchett - Consultant, Resource Project, Eaglewood, Colorado

3. Frank Mabry - Consultant (Petroleum Geologist), Mabry, F. C., Cedar Park, Texas

4. Kevin McNichols - Consultant, Hite, Powers and Associates, Inc.

5. Wyne Zeimienski - Area Manager, TEXACO

6. Warren K. Kourt - Consulting Professor, Petroleum Engineering Department, Stanford University

7. Laurie Brough - Senior Staff Geological Consultant, Canadian Occidental Petroleum Ltd. 